\title{
Megaclasts in geoconservation: sedimentological questions, anthropogenic influence, and geotourism potential
}

\author{
Katrin A. Lubova ${ }^{1}$, Pavel P. Zayats ${ }^{2}$, Dmitry A. Ruban ${ }^{3 *} \&$ Günter Tiess ${ }^{4}$ \\ ${ }^{1}$ Department of Physical Geography, Ecology, and Nature Protection, Institute of Earth Sciences, \\ Southern Federal University, Zorge Street 40, Rostov-na-Donu, 344090, Russia \\ ${ }^{2}$ Camp for Practice and Educational Tourism 'Belaja Retchka' ('White River'), Southern Federal University, Nikel', \\ Majkop District, Republic of Adygeja, 385792, Russia \\ ${ }^{3}$ Department of Mineralogy and Petrography, Institute of Earth Sciences, Southern Federal University, \\ Zorge Street 40, Rostov-na-Donu, 344090, Russia; postal address: P.O. Box 7333, Rostov-na-Donu, 344056, Russia; \\ e-mail: ruban-d@mail.ru \\ ${ }^{4}$ Chair of Mining Engineering and Mineral Economics, Department of Mineral Resources and Petroleum Engineering, \\ University of Leoben, Franz-Josef-Strasse 18, A-8700 Leoben, Austria \\ * corresponding author
}

\begin{abstract}
Megaclasts are sedimentary particles larger than boulders. Their huge size and scattered occurrence make them objects that deserve geological heritage, requiring conservation. Investigation of megaclasts for the purpose faces difficulties because of the distinction between boulders and megaclasts. Local study of Quaternary large stones in Mountainous Adygeja (W Caucasus, SW Russia) suggests $~ 2 \mathrm{~m}$ as a suitable size criterion, although only locally. Shape, occurrence, and origin of megaclasts require additional attention.

Geoconservation may result in anthropogenic disturbances of the natural landscape through removal of vegetation, access constructions, and restoration. The geotourism potential of megaclasts is partly determined by their huge size and their rare and scattered occurrence. Aesthetic qualities, local legends, and co-occurrence with prehistoric megalithic constructions increase this potential. The Maiden's Stone in Mountainous Adygeja, which is $35 \mathrm{~m}$ long, has been a tourist attraction already for decades. It is an impressive example of geoconconservation and geotourism connected with megaclasts. Generally, megaclasts increase the value (including the scientific importance) of the geological heritage of Mountainous Adygeja, where a geopark might be established.
\end{abstract}

Keywords: megaclasts, rockfall, geoconservation, geotourism, Western Caucasus

\section{Introduction}

Conservation of geological heritage (geoconservation) is a rapidly-developing activity worldwide (Wimbledon et al., 1995, 1998; Gray, 2004, 2008; Prosser et al., 2006; 2011; Wimbledon \& Smith-Meyer, 2012; Prosser, 2013). It deals with a wide spectrum of geological objects, which should first be recognised as worth being conserved and subsequently saved in situ as unique sources of information about the Earth and its evolution. Although some geological processes (rock avalanches, tsunamis, etc.) may result occasionally in the formation, transportation, and voluminous accumulation of megaclasts, whole layers composed of such large particles are hard to find (see a rare example in Tost et al., 2012). Extraordinary large 
stones are potential geological heritage sites (geosites) and can be used for scientific, educational, and tourism/recreation purposes (Gray, 2004, 2008; Ruban, 2010a; Ruban \& Kuo, 2010; Prosser et al., 2011).

Large stones (> $2 \mathrm{~m}$ in size), individually or in groups, are known as megaclasts (Blott \& Pye, 2012). They feature strongly amongst potential geosites (Fig. 1). Their huge size and scattered occurrence determine their rarity and, consequently, their uniqueness (Pugatchev \& Ruban, 2007). The physical dimensions of large blocks fallen from a slope by the 2006 rockfall in Umbria (Italy) (Guzzetti, 2013) and of those emplaced by past tsunami's on the shore of Oahu Island (Hawaii, USA) (Noormets et al., 2002, 2004) demonstrates the strength of the geological forces involved. The Eusigne Pyramids (Pyramides d'eusigne) in Valais (Switzerland) (Reynard, 2009) and the enigmatic group of large stones over $8 \mathrm{~km}^{2}$ in Western Transbaikalia (southern Siberia, Russia) (Ufimtsev et al., 2004) show peculiar ways in which the Earth's surface is shaped. Megaclasts are complex objects with unique sedimentological and geomorphological features that cannot always be separated (Pugatchev and Ruban, 2007; see also the review of geosite types by Ruban \& Kuo, 2010).

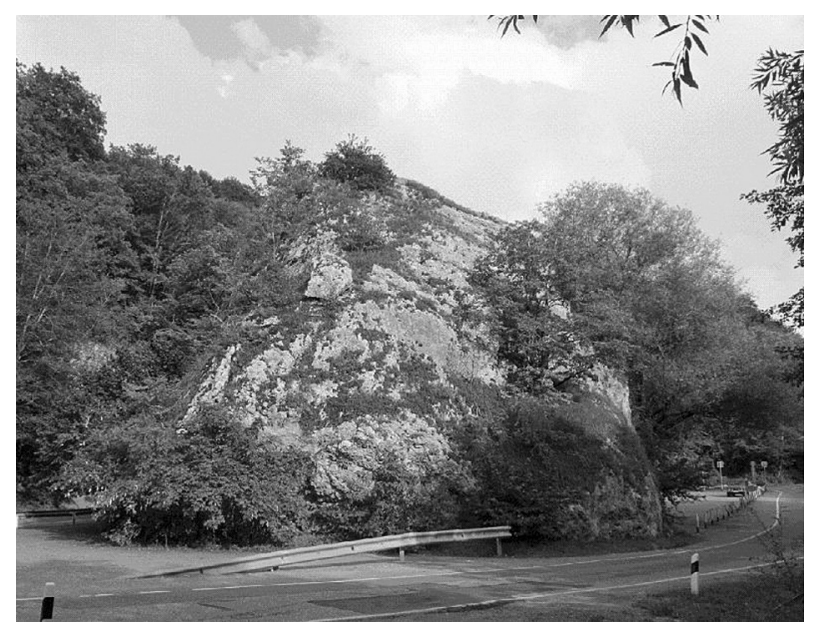

Fig. 1. The Maiden's Stone (general view from the north-east), a large megaclast, which is an important landmark separating the lanes of the road in the Khadzhokh Canyon. It is protected as a republican monument of nature since 1973, and it is also a geological heritage site. Car in the lower right corner for scale. See Figure 2 for location and Appendix for description. Photo by P.P.Z.
Traditional geoconservation methods, techniques and legal procedures, i.e., formal recognition of geosites, making them accessible to visitors, allowing establishment of their official status of protected sites, etc. (Wimbledon et al., 1995; Prosser et al., 2006; Ruban, 2006; Wimbledon \& Smith-Meyer, 2012; Prosser, 2013), can be applied to megaclast geosites. Here, we attempt to shed light on three important management aspects, namely their proper sedimentological description, anthropogenic influence due to geoconservation procedures, and evaluation of the geotourism potential. Our general considerations are in particular based on the examination of megaclast-related geosites in Mountainous Adygeja, which is a territory with a spectacular nature (e.g., Trepet, 2011, $2012,2013)$ and with the richest geological heritage in the W Caucasus (SW Russia) (Ruban

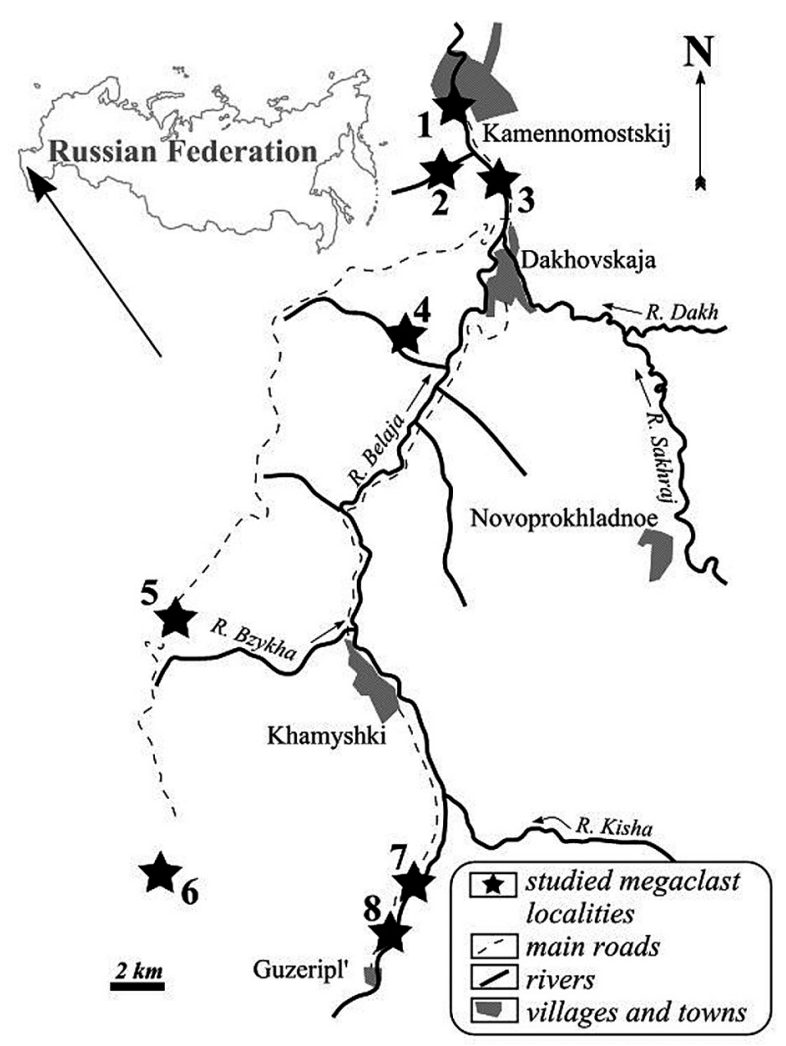

Fig. 2. Localities of megaclasts in Mountainous Adygeja under study. 1 = Khadzhokh Klamm, 2 = Rufabgo Canyon, 3 = Maiden's Stone, 4 = Prince's Hill (Wildpig Mountain), 5 = Azish-Tau Range, $6=$ Stonesea Range, 7 = Permian Gorge, $8=$ Guzeripl' $^{\prime}$ Rockfall. See Appendix for descriptions. 
\& Pugatchev, 2008; Ruban, 2010a, b). There, Quaternary megaclasts of various size, shape, and origin occur almost everywhere (Fig. 2, Appendix; see also Pugatchev \& Ruban, 2007).

\section{Sedimentological description of megaclasts for geoconservation purposes}

Evaluation of geosites requires their accurate geological characterisation (Wimbledon et al., 1995; Prosser et al., 2006; Ruban, 2006). In the case of megaclasts, this may include size, shape, age of detachment, pre-detachment situation, transport, and subsequent weathering. Megaclasts are essentially large sedimentary particles (Blair \& McPherson, 1999; Blott \& Pye, 2012), and therefore need proper sedimentological descriptions. One of the questions is what classification system(s) should be applied. Generally, a description can be accomplished with a 'standard' approach (Folk, 1974; Pettijohn, 1975; Boggs, 2006; Blott \& Pye, 2008, 2012; Nichols, 2009; Tucker, 2011; Farrell et al., 2012), but such approaches do not always properly take into account the megaclasts' nature. This is regrettable since it is precisely their size that determines the geological-heritage merit of megaclasts (Pugatchev \& Ruban, 2007). Also, their roundness, distribution and provenance require special consideration.

A detailed classification of coarse sedimentary particles was proposed more than a decade ago by Blair \& McPherson (1999). They coined the term 'megagravel' to describe the fraction of particles larger than $4096 \mathrm{~mm}$, and they also subdivided megagravel particles into blocks (4.1-65.5 m), slabs (65.5-1048.6 m), monoliths $(1-33.6 \mathrm{~km})$, and megaliths (33.6-1075 $\mathrm{km}$ ); each of these four classes was subdivided into four or five grades. Practically, particles larger than blocks are difficult to be recognised in nature (but, of course, they may exist). An alternative classification was proposed by Blott \& Pye (2012), who changed the range of boulders to 64-2048 $\mathrm{mm}$ and termed particles larger than $2048 \mathrm{~mm}$ 'megaclasts'. In other words, megaclasts in their classification include also the particles termed as 'very coarse boulders' by Blair \& McPherson (1999). Both alternative classifications can be employed for descriptions of megaclasts for geoconservation purposes, and the preferred approach should be always indicated properly.

The megaclasts in Mountainous Adygeja vary in size (Figs 1,3), but they are usually somewhat larger than $2 \mathrm{~m}$, i.e., very coarse boulders and not megaclasts according to the classification proposed by Blair \& McPherson (1999). Only the Maiden's Stone (Fig. 1) and a few huge stones in the Rufabgo Canyon and the northern part of the Khadzhokh Klamm (Fig. 3B, I) belong to the class of blocks. The classification of Blott \& Pye (2012), in contrast, permits to consider many stones as megaclasts, co-occurring with boulders. This classification is preferred here for two reasons. In the first place, the 'value' of large stones as geological heritage is more pronounced if they distinctly influence the geological scenery. In the Rufabgo Canyon, for instance, only stones of $\sim 2-4 \mathrm{~m}$ make the landscape peculiar and strikingly different from the 'usual' alluvial deposits. In the second place, each geosite evaluation should take geotourism development into account. Visitors will pay most attention to man-sized or larger stones. Therefore, if the classification of Blair \& McPherson (1999) is applied to the huge stones in the Rufabgo Canyon or to the Guzerpl' Rockfall, the truly large particles are classified with the same term as those which are much smaller; this does consequently not permit to differentiate between stones with geoconservation and geotourism value from the other stones. In contrast, the classification proposed by Blott \& Pye (2012) solves this problem successfully. Measuring megaclasts is difficult (partly due to their often irregular shape), and, thus, a visible length of $\sim 2 \mathrm{~m}$ (and not exactly 2048 $\mathrm{mm}$ ) was preferred as the 'boundary' between boulders and megaclasts in the present study. Probably, the traditional Soviet/Russian classification, which makes a distinction between boulders and blocks at a size of $1 \mathrm{~m}$ (e.g., Paffengol'ts, 1978; Logvinenko, 1980), would also be effective in the practice of geoconservation. 

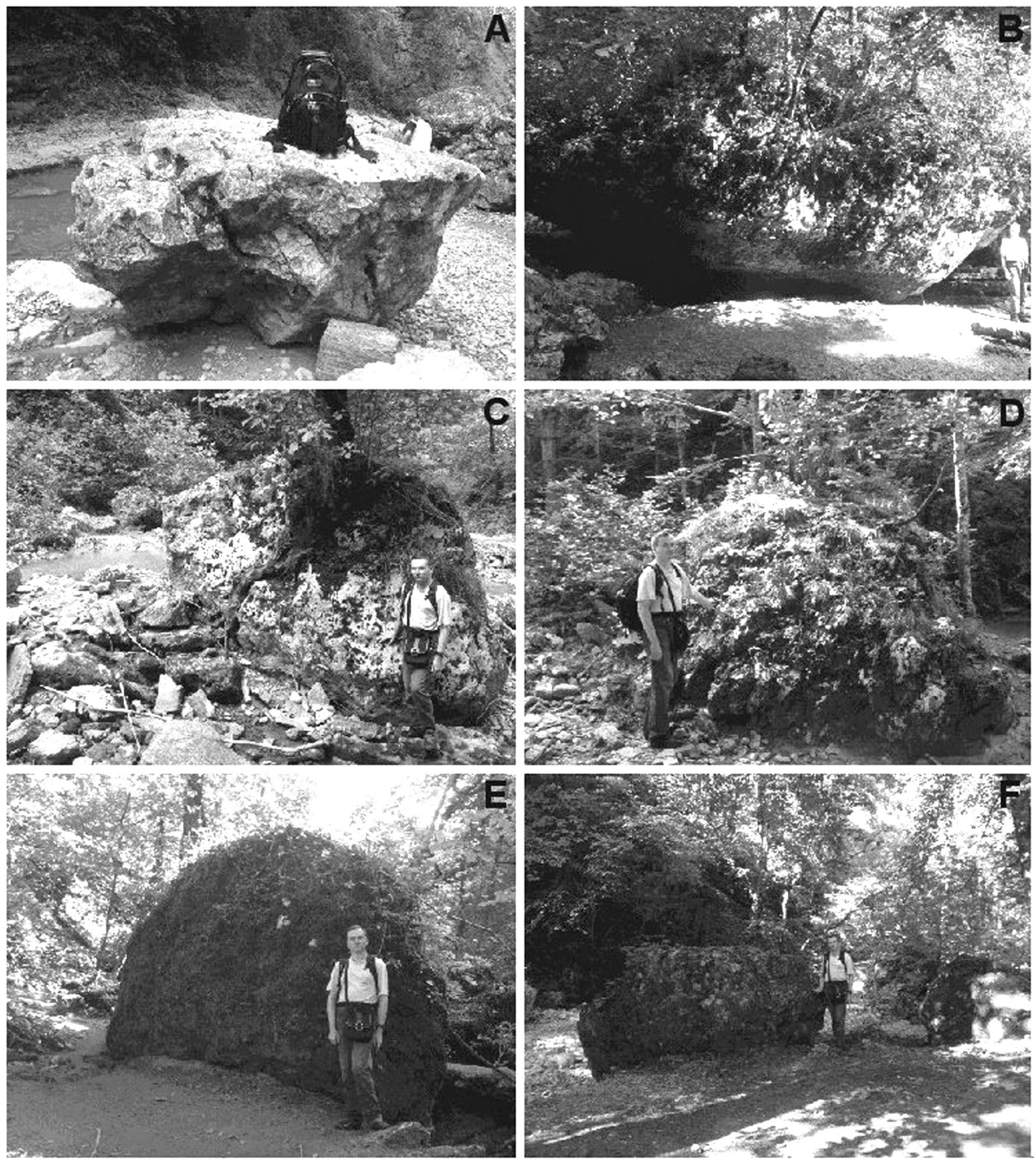

Fig. 3. Some megaclasts in Mountainous Adygeja. Localities: A-F = Rufabgo Canyon, $\mathbf{G}=$ Stonesea Range, $\mathbf{H}, \mathbf{I}=$

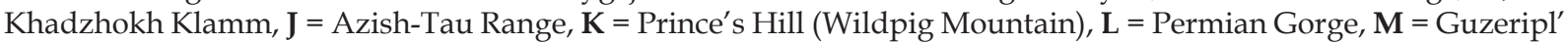
Rockfall. Field bag ( $\sim 50 \mathrm{~cm}$ high) for scale in Fig. 3A; D.A.R. for scale in Figs 3B-F, I, K-M; length of stone is $\sim 2 \mathrm{~m}$ in Fig. 3G; K.A.L. for scale in Fig. 3J. See Figure 2 for location and Appendix for descriptions. Photos A-I, K by K.A.L., photo J by D.A.R., photos L, M by P.P.Z.

The shape of megaclasts can be evaluated with 'standard' approaches (Krumbein, 1941; Powers, 1953; Folk, 1974; Pettijohn, 1975; Boggs, 2006; Tucker, 2011). Blott \& Pye (2008) offer a more advanced technique, which can also be employed in megaclast-related geoconservation investigations. Because the megaclasts of Mountainous Adygeja are mainly the result of gravitational processes, they are more or less angular (Fig. 3). However, some megaclasts from the Rufabgo Canyon show a certain (sometimes considerable) rounding (Fig. 3B-E). This is explained in two ways: (1) the Rufabgo River activity polishes and rounds particles transported and deposited downstream, and (2) some large stones were formed by collapse of polished valley walls in the upper level of the canyon; detachment of large particles 

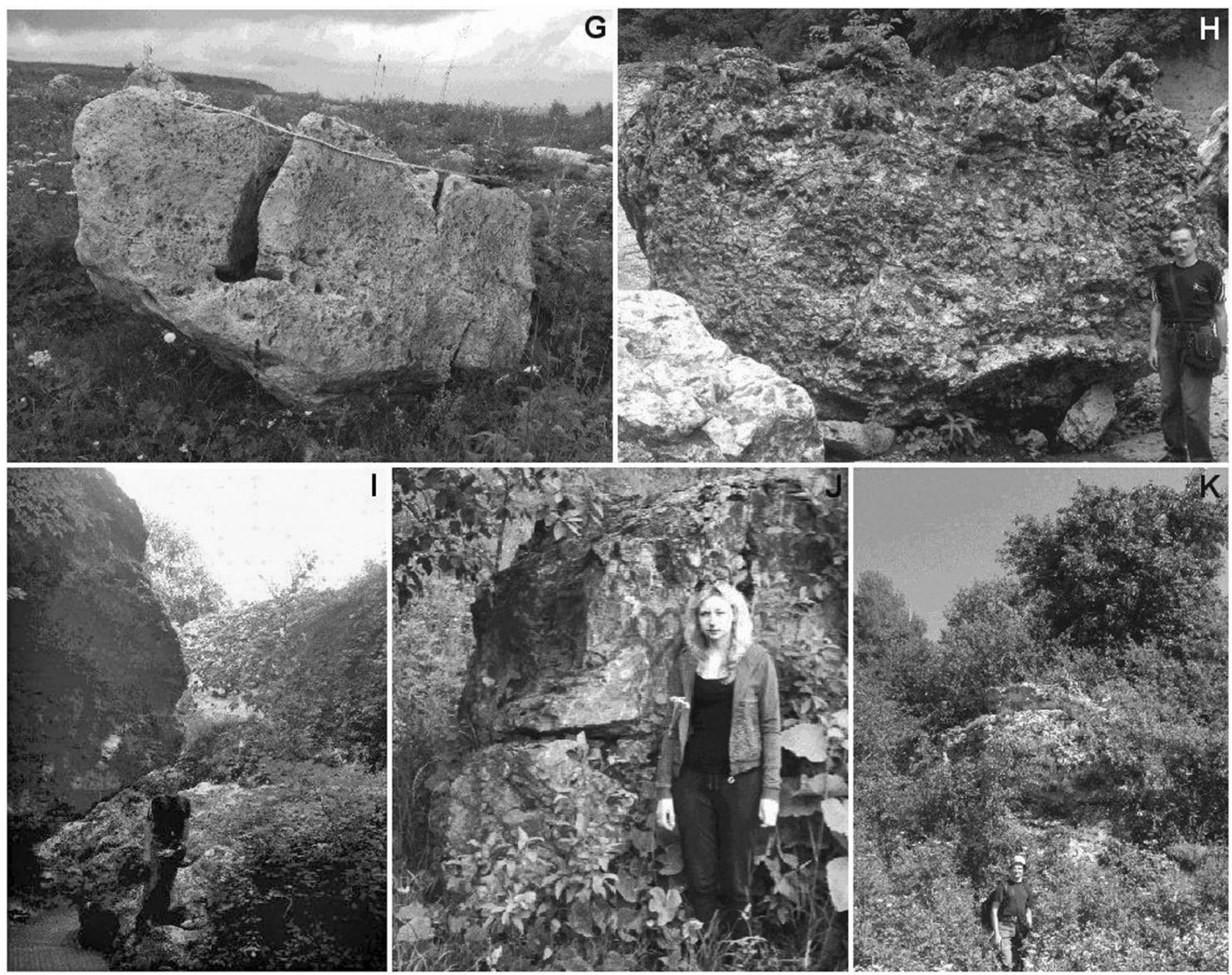

Fig. 3. cont.

from these valley walls has been controlled by pre-existing erosional and karst fissures. Intense karst processes on the Stonesea Range (Lozovoj, 1984) also smoothed the shape of megaclasts occurring at its top (Fig. 3G).

Observations of megaclasts in Mountainous Adygeja permits to classify their occurrence using two parameters. The first parameter is their distribution. Megaclasts can occur either as isolated features like the Maiden's Stone (Fig. 1) or in groups like some large stones in the Rufabgo Canyon. The second parameter is the possible co-existence with boulders, such as in the case of the Guzeripl' Rockfall (Fig. 4).

The origin of megaclasts may differ significantly (cf. Blair \& McPherson, 1999). While it is evident that large stones of the Guzeripl' Rockfall were formed as a result of gravitational processes affecting the steep slope (Fig. 4), it is less clear whether only natural mass wasting has resulted in the megaclast accumulation in the roadcuts at the toe of the Azish-Tau Range and in the Permian Gorge (Fig. 3L). On the one hand, some large stones might have been detached from the rock mass when the roads were constructed. On the other hand, ongoing road exploitation may itself affect slope stability. The past and present influence of road construction/maintenance on the shape of the Maiden's Stone is unclear and requires systematic measurements over an extended time. A different example is the Rufabgo Canyon, where river incision promotes slope instability, and where large particles have already fallen or slid directly to the stream; they were evidently eroded and shaped by the river current (see also above).

The above considerations imply that sedimentological descriptions of megaclasts for geoconservation purposes should take into account the entire cycle of formation, transportation, accumulation, and shaping of these large particles and also the geomorphological and geological evolution of the area. The megaclasts of Mountainous Agydeja are Quaternary in age, and further geoconservation research 


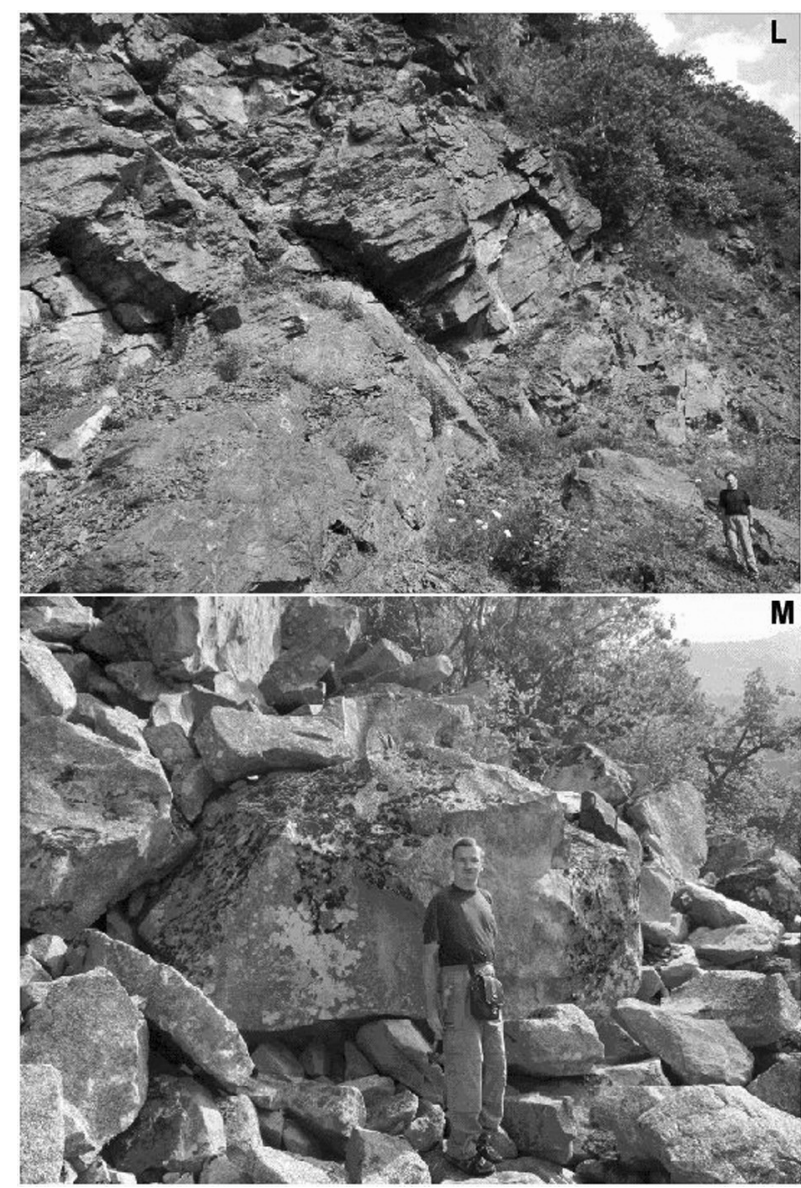

Fig. 3. cont.

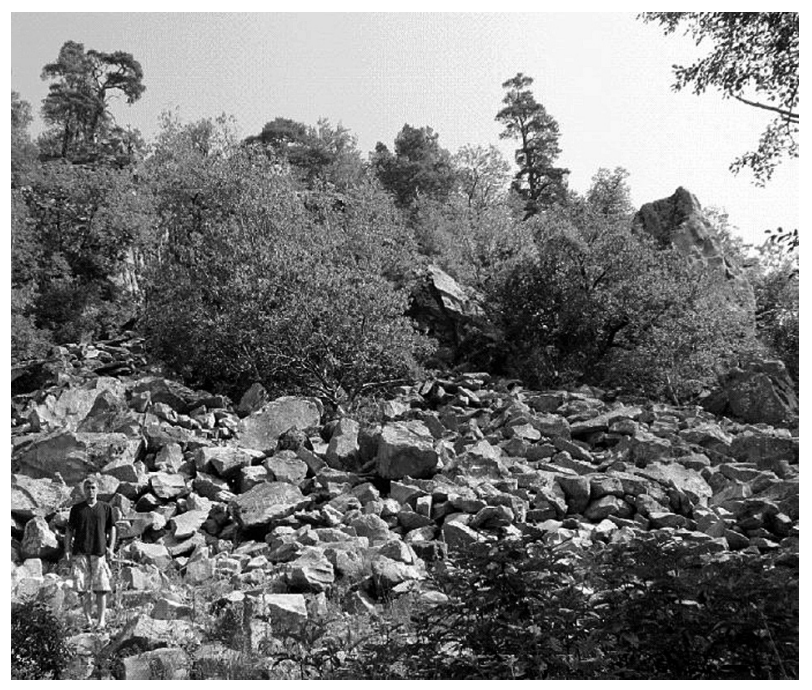

Fig. 4. The Guzeripl' Rockfall. See Figure 2 for location and Appendix for description. P.P.Z. for scale. Photo by D.A.R.

should pay special attention to megaclasts in lithified rocks like those described by Tost $e t$ al. (2012).

\section{Anthropogenic influence related to megaclast conservation}

Geosites need protection from human activities with negative consequences for the site or its natural environment; activities such as road construction, waste disposal, oversampling for scientific or educational purposes, destruction by visitors may be harmful (Prosser et al., 2006; Ruban \& Kuo, 2010). A clear example is one megaclast at the toe of the Azish-Tau Range, on which graffiti were painted (see the large drawn heart in Fig. 3J). Also geoconservation itself, however, can act as a negative anthropogenic influence.

Geosite management involves two types of activity. The first is cleaning of the object (by, for instance, removal of vegetation and soil) for better exposure of peculiar features. This evidently affects their natural state. It may be dangerous; trees may grow on large stones, underlining their peculiarity and heritage value (Fig. 3C), which are commonly especially appreciated by tourists. Moreover, some megaclasts in Mountainous Adygeja are covered by so-called 'stone-breaking' lichens, which affect the shape of these sedimentary particles. The presence of these lichens increases the scientific value of megaclasts, because they may also be important for the evaluation of the age of stones and of the events which produced them (earthquakes, rockfalls, etc.) by means of lichenometry (Bull, 2007). The second type of activity is related to providing access to the geosites, which may require engineering works like building trails and bridges, as in the case of the Khadzhokh Klamm (visible in the left corner of Fig. 3I). This makes it possible for visitors to observe the power of the river current in the narrow valley. Although megaclasts in Mountainous Adygeja were not affected strongly by such actions, it may occur elsewhere, where megaclasts may also be broken, transported, or completely destroyed (in particular when no thorough geoconservation-management plan exists).

Some geosites have also been damaged by natural processes or by human activity, and they may be further restored. One example is Pedralta (Girona, Spain), where a huge stone with an 
approximate volume of $38 \mathrm{~m}^{3}$ and a length of $6.2 \mathrm{~m}$ - which was located in isolation at the top of a group of leucogranitic blocks - fell down in December, 1996; this was possibly a natural event, but it may as well have been the result of human intervention in the form of an accumulation of broken glassware (bottles, glasses, etc.) (Pallí \& Roque, 1999). If the latter is true, this geosite shows that recognition of the peculiarity of a geological phenomenon may attract so much public attention that this results in damage (in other words, geoconservation may increase the risk of geosite damage). A few years later, the fallen rock was uplifted to the top again; the new position of the megaclast differs, however, from its original position (Pallí \& Roqué, 1999). On one hand, this action saved a natural landmark in an earlier state. On the other hand, the action may have been an unnatural intervention, if the megaclast fell because by strictly natural causes. The attempt to restore this peculiar geosite may thus have changed the natural local geomorphic evolution. In other words, it can well be that the geosite in its current state is artificial in essence, although only so its original value could be preserved. Situations like this pose a great dilemma that is typical for the practice of nature restoration (Allison, 2012).

An even more interesting example of anthropogenic influence is linked with purposely erected large stones such as the large polished peridotite stones on the square of the town of Samani (Hokkaido, Japan), exhibit the local geological heritage (Arita et al., 2003). Earlier, Legget (1973) noted the presence of large rocks in a street in Ottawa (Canada). In the both cases, the stones are megaclasts (some are nearly megaclasts) as regards their size, but they have been extracted by humans from their natural geological environment, transported, and installed in a new place for geoconservation purposes.

Finally, geoconservation and geotourism create new values of geological objects, which may change the perception of these objects. Generally, visitors would not pay attention to an 'ordinary' megaclast (although they might occasionally notice its huge size), but they will look at it with special attention when the stone is promoted as geological heritage and as something peculiar that is so important that conservation is required. Cleaning of geosites for better exposure or access help the public recognising the value of geosites and their features. Geoconservation and geotourism may, however, also induce aesthetic damage (cf. Reynard, 2009). The Maiden's Stone in Mountainous Adygeja is an example. Much place is reserved there for cars, buses with tourists, and souvenir vendors, just in front of this geosite (Fig. 1). This makes this geosite looking a bit unnatural.

Struggling with all these negative consequences of geoconservation is a serious challenge, which requires careful long- and shortterm planning of conservation activity, as well as networking with local education and tourism institutions. Generally, the available 'algorithms' of geoconservation activity (e.g., Prosser, et al., 2006) allow such planning and networking, but practitioners should be well aware of the specific issues mentioned above. Another important subject for further debate is the geoconservation utility of megaclasts, which are by-products of quarrying. Besides direct anthropogenic influences, many attempts to conserve quarrying sites (also as a kind of geoheritage) would disturb large stones accumulating in/near them, and it is unclear whether the current mineral policy (Tiess, $2011 a, b)$ would solve the relevant problems effectively (see also discussions in QPASMSA, 2003; Tiess \& Ruban, 2013).

\section{Evaluation of the geotourism potential of megaclasts}

Geotourism grows in tandem with geoconservation, sometimes even more rapidly (Hose, 1996, 2000; Hose \& Wickens, 2004; Gray, 2008; Dowling \& Newsome, 2010; Ruban \& Kuo, 2010; Gordon, 2012; Hose \& Vasiljević, 2012; Liccardo et al., 2012).

In Mountainous Adygeja, this kind of tourism is not yet well-developed, but this territory makes the occurrence of a megaclast, which has attracted tourists already for many decades, ever better known. This is the Maiden's Stone, which is located between of the town of 
Kamennomostskij in the North and the village of Dakhovskaja in the South (Fig. 2). This angular to subangular and elongated stone has a length of $\sim 35 \mathrm{~m}$ and a height of $\sim 10 \mathrm{~m}$. It lies halfway the eastern slope of the Khadzhokh Canyon and now divides the lanes of the road (Figs. 1, 5; Appendix). It is the result of cliff collapse at the edge of the cuesta-type Unakoz Range, which makes it colluvial in origin. The Maiden's Stone is protected as a regional natural monument since 1973, and it is a very popular tourist destination (particularly, because it is situated in the midst of the popular tourist route stretching along the canyon). A large area south of the geosite is reserved for the parking of cars and buses, and for souvenir shops (Fig. 5B). This geosite attracts tourists for two reasons. The first is its huge size (there is a common local belief that this is 'the largest boulder of Europe', although this is unlikely to be true - not in the least because the area lies geographically in Asia. The second reason is the local legend that a young lady climbed the top of this stone on horseback, which explains the origin of the stone's name.

The geotourism potential of megaclasts is determined by several factors. The example of the Maiden's Stone demonstrates their unusually large size and cultural interpretation. The large size demonstrates the power of catastrophic geological processes (e.g., it is supposed that the Maiden's Stone formed through quick rolling or sliding of the block downslope, probably triggered by gravity or even an earthquake). Such large sedimentary particles, especially blocks and slabs in the sense of Blair \& McPherson (1999), are rare and attract the attention of professionals and students alike. Legends and common local views on megaclasts link the geological scenery with local socio-cultural life. Tracing such links may be highly attractive for tourists.

More important factors exist that determine the geotourism potential. Megaclasts occurring either as isolated stones or in groups diversify the landscape, and increase its aesthetic value (cf. Pugatchev \& Ruban, 2007). Such large stones are valuable as geomorphological features (see above), and often (if not always) have significant aesthetic qualities (Reynard,

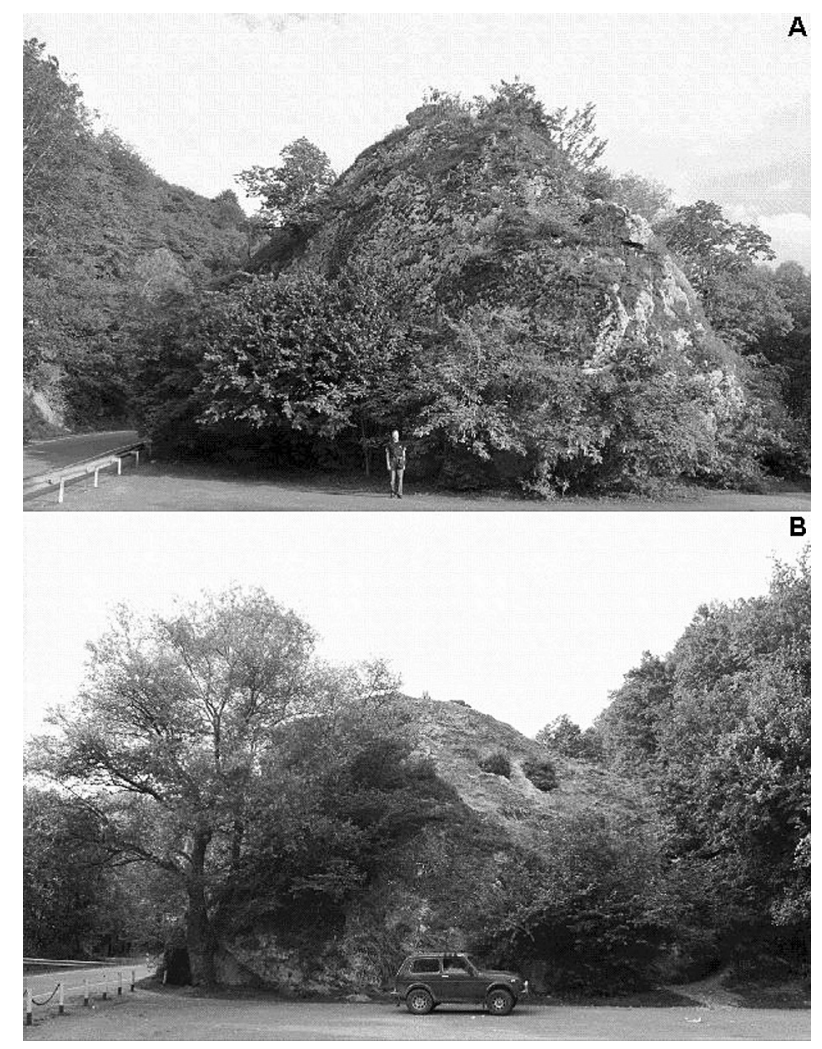

Fig. 5. The Maiden's Stone (A: view from the north; B: view from the south). See also Figure 1 for another view; see Figure 2 for location and Appendix for description. D.A.R. for scale in Fig. 5A, and car for scale in Fig. 5B. Photos by P.P.Z.

2009). Sometimes, groups of megaclasts like those on the slope of the Prince's Hill resemble architecture and park design and, particular$l y$, the famous Japanese 'stone gardens'. Once the natural origin of such megaclast groups is realised, it may excite tourists. Thus, cultural dimensions in landscape perception may promote interest in geological features, which will serve geotourism. Moreover, megaclasts, which often are perceived as something more than 'just stones' because of their size and rarity, may also resemble or even truly represent prehistoric human constructions. The latter are widespread in Eurasia (e.g., Markovin, 1978; Parry, 2000; Lutaenko et al., 2007; Clare, 2010) and, particularly, in Mountainous Adygeja, where megalithic constructions (known as 'dolmens') are numerous; some of them (e.g., the dolmen in Guzeripl' or the ancient settlement near the Doguako River) are located near by megaclast localities (Markovin, 1978; Trepet, 2011). Such enigmatic constructions are 
popular visiting targets and are prominent features in local tourism programs in Mountainous Adygeja. The resemblance between natural megaclasts and man-made megaliths may enhance the correct perception of the uniqueness of both. This kind of interest in megaclasts is further enhanced by the local occurrence of an internationally-known Neanderthal site: the Mezmaiskaya Cave (Ovchinnikov et al., 2000; Straus, 2005; Pinhasi et al., 2011; Doronicheva et al., 2012). On the one hand, this Stone Age site directs attention to all huge stones known locally. On the other hand, tourists may perceive megaclasts in a broader perspective, i.e., linking Quaternary mountain development and slope movements with human inhabitation of the territory.

Generally, the geotourism potential of megaclasts depends on their value as rare geological objects, but cultural and archaeological values enhance their value. However, this poses a serious challenge for local tourism management; it requires a proper explanation of the geological origin of the large stones. Unrealistic mixing of scientific and fantasy interpretations should be avoided. This is important because many geotourists are only occasional visitors without an appropriate background in the earth sciences (Hose, 2000; Hose \& Wickens, 2004). The megaclasts of Mountainous Adygeja with their complex and sometimes uncertain origin require sound professional explanations to to inform unprepared visitors in an adequate way. The idea of colluvium may be elementary to earth scientists, but not to occasional tourists whose attention may be focused on cliffs and mountain tops (often far away from megaclast localities that are poorly or not visible at all because of dense vegetation); the possible causes of slope collapse should therefore be explained in a form that is both scientifically correct and understandable for non-specialists. Even newly arrived specialists, unfamiliar with Mountainous Adygeja and the regional geology, may have difficulties to understand why the megaclasts in the Rufabgo Canyon (Fig. 3A-F) consist of massive limestone, which is different from the outcropping Triassic flysch in the lower level of the canyon (the reason is that the upper level of the deep canyon, cut in Late
Jurassic carbonates, remains almost entirely invisible from the bottom).

Modern geotourism development is linked to geoparks (Gray, 2008; Dowling \& Newsome, 2010; Prosser, 2013), which form a global network based on international initiatives (Geoparks Secretariat, 2006). Mountainous Adygeja, being outstanding for its geodiversity, is very suitable for becoming a geopark (Ruban, 2010a, b). The local development of geotourism can profit from three factors. In the first place, it has remained a popular national tourist destination for several decades; nature-based tourism (with some elements of ecotourism) prevails (Lozovoj, 1984; Trepet, 2011). In the second place, this destination is well in reach of international tourists, as it is situated close to Sochi, which is the place of the 2014 Winter Olympics. In the third place, the Caucasus State Natural Biosphere Reserve with its high tourism potential already occupies part of this territory. Preparing a detailed geopark proposal (with the selection of geosites, a management plan, an environmental assessment, etc.) according to the rules (Geoparks Secretariat, 2006) is a task for the future, but it emphasised here that the diversity and the abundance of megaclasts in Mountainous Adygeja (Appendix; Fig. 2) increases the value of its geological heritage and makes the idea of a local geopark even more promising.

\section{Conclusions}

Megaclasts known worldwide and, particularly, in Mountainous Adygeja are important geosites. Numerous benefits follow from successful management of protected areas (Dudley et al., 2010). Undoubtedly, megaclast geosites will bring benefits too. However, the investigations preceding geoconservation faces a serious challenge, namely the proper classification by size. Available classifications (Blair \& McPherson, 1999; Blott \& Pye, 2012) use different criteria to separate between boulders and megaclasts. In the region under study, a size of $\sim 2 \mathrm{~m}$ appears to be the most suitable for distinguishing between these two groups of particles, and this distinction appears useful 
for geoconservation studies. Conservation of large stones may, however, induce anthropogenic influence, especially when special access constructions are required, or when restoration is needed. Finally, the geotourism potential of megaclasts is determined by their physical parameters, aesthetic qualities, and associated cultural values.

This study of megaclasts in Mountainous Adygeja shows the diversity of these objects (Fig. 3), the complexity of their interpretations, and the necessity of adequate solutions for successful management. Consequently, this territory can be regarded as a test site for megaclast conservation. The present contribution reflects preliminary views on some issues. Further research of the large stones may change these views and bring new ideas.

\section{Acknowledgements}

The authors gratefully thank K. Arita (Japan), D. Barettino (Spain), C.P. Conrad (USA), E.A. Felton (USA), W. Riegraf (Germany), G.F. Ufimtsev (Russia), W.A.P. Wimbledon (UK), and many more specialists for literature supply, as well as their colleagues (especially A.S. Tchikhatchev and A.E. Tsygankova) from the Southern Federal University (Russia) for field assistance. Part of this work is the result of the 2013 field practice for the degree of bachelor in geography by K.A.L., which was organised by the Southern Federal University.

\section{References}

Allison, S.K., 2012. Ecological restoration and environmental change: renewing damaged ecosystems. Routledge, London, $245 \mathrm{pp}$.

Arita, K., Maeda, J. \& Niida, K., 2003. Deep-seated plutonic and metamorphic rocks of the Hidaka Mountains, Hokkaido. XXIII General Assembly of the International Union of Geodesy and Geophysics. Field Trip Guidebook. The Volcanological Society of Japan, 265-308.

Blair, T.C. \& McPherson, J.G., 1999. Grain-size and textural classification of coarse sedimentary particles. Journal of Sedimentary Research 69, 6-19.

Blott, S.J. \& Pye, K., 2008. Particle shape: a review and new methods of characterization and classification. Sedimentology 55, 31-63.

Blott, S.J. \& Pye, K., 2012. Particle size scales and classification of sediment types based on particle size distributions: Review and recommended procedures. Sedimentology 59, 2071-2096.
Boggs, S., Jr., 2006. Principles of sedimentology and stratigraphy. Pearson Prentice Hall, Upper Saddle River, 662 pp.

Bull, W.B., 2007. Tectonic geomorphology of mountains: a new approach to paleoseismology. Blackwell, Malden, $316 \mathrm{pp}$.

Clare, T., 2010. Megalith size and the implications for our understanding of contemporary society, with particular reference to Cumbria, North-West England. Oxford Journal of Archaeology 29, 245-252.

Doronicheva, E., Kulkova, M. \& Grégoire, S., 2012. La grotte Mézmaiskaya (Caucase de Nord): Exemple de l'utilisation des matières premières lithique au Paléolithique Moyen et Supérieur. Anthropologie 116, 378-404.

Dowling, R. \& Newsome, D., 2010. Geotourism: a global activity. [In:] R. Dowling \& D. Newsome (Eds): Global geotourism perspectives. Goodfellow Publishers, Woodeaton, 1-17.

Dudley, N., Hocking, M. \& Stolton, S., 2010. Precious places: getting the arguments right. [In:] S. Stolton \& N. Dudley (Eds): Arguments for protected areas: multiple benefits for conservation and use. Earthscan, London, 253-264.

Farrell, K.L., Harris, W.B., Mallinson, D.J., Culver, S.J., Riggs, S.R., Pierson, J., Self-Trail, J.M. \& Lautier, J.C., 2012. Standardizing texture and facies codes for a process-based classification of clastic sediment and rock. Journal of Sedimentary Research 82, 364-378.

Folk, R.L., 1974. Petrology of sedimentary rocks. Hemphill Publishing Company, Austin, 182 pp.

Geoparks Secretariat, 2006. Guidelines and criteria for national geoparks seeking UNESCO's assistance to join the Global Geoparks Network. Episodes 29, 115-118.

Gordon, J.E., 2012. Rediscovering a sense of wonder: geoheritage, geotourism and cultural landscape experiences. Geoheritage 4, 65-77.

Gray, M., 2004. Geodiversity: valuing and conserving abiotic nature. J. Wiley, Chichester, 434 pp.

Gray, M., 2008. Geodiversity: developing the paradigm. Proceedings of the Geologists' Association 119, 287-298.

Guzzetii, F., 2013. Rockfall. [In:] P.T. Bobrowsky (Ed.): Encyclopedia of Natural Hazards. Springer, Dordrecht, 875-877.

Hose, T.A., 1996. Geotourism, or can tourists become casual rock hounds? [In:] M.R. Bennett, P. Doyle, J. Larwood \& C.P. Prosser (Eds): Geology on your doorstep: the role of urban geology in earth heritage conservation. Geological Society, London, 207-228.

Hose, T.A., 2000. European 'geotourism' - geological interpretation and conservation promotion for tourists. [In:] D. Barettino, W.A.P. Wimbledon \& E. Gallego (Eds): Geological heritage: its conservation and management. ITGE, Madrid, 127-146.

Hose, T.A. \& Wickens, E., 2004. Typologies, tourism locations and images: meeting the real needs of real tourists. [In:] S. Weber, R. Tomljenović (Eds): Reinventing a tourism destination: facing the challenge. Institute for Tourism, Zagreb, 103-114.

Hose, T.A. \& Vasiljević, D.A., 2012. Definig the nature and purpose of modern geotourism with particular 
reference to the United Kingdom and south-east Europe. Geoheritage 4, 25-43.

Krumbein, W.C., 1941. Measurement and geological significance of shape and roundness of sedimentary particles. Journal of Sedimentary Petrology 11, 64-72.

Legget, R.F., 1973. Cities and geology. McGraw-Hill, New York, $624 \mathrm{pp}$.

Liccardo, A., Montesso-Neto, V. \& Piekarz, G.F., 2012. Urban geotourism - Education and culture. Anuario do Instituto de Geociencias 35, 133-141.

Logvinenko, N.V., 1980. Morskaja geologija. [Marine geology]. Nedra, Leningrad, 343 pp. (in Russian).

Lozovoj, S.P., 1984. Lagonakskoe nagor'e. [The Lagonaki highlands]. Krasnodarskoe knizhnoe izdatel'stvo, Krasnodar, 160 pp. (in Russian).

Lutaenko, K.A., Zhushchikhovskaya, I.S., Mikishin, Yu.A. \& Popov, A.N., 2007. Mid-Holocene climatic changes and cultural dynamics in the basin of the Sea of Japan and adjacent areas. [In :] D.G.Anderson, K.A. Maaschn \& D.H. Sandweiss (Eds): Climate change and cultural dynamics: a global perspective on Mid-Holocene transitions. Academic Press, London, 331-406.

Markovin, V.I., 1978. Dol'meny Zapadnogo Kavkaza. [Dolmens of the Western Caucasus]. Nauka, Moskva, 328 pp. (in Russian).

Nichols, G., 2009. Sedimentology and stratigraphy. Wiley-Blackwell, Oxford, 419 pp.

Noormets, R., Felton, E.A. \& Crook, K.A.W., 2002. Sedimentology of rocky shoreline, 2: Shoreline megaclasts on the north shore of Oahu, Hawaii - origins and history. Sedimentary Geology 150, 31-45.

Noormets, R., Felton, E.A. \& Crook, K.A.W., 2004. Sedimentology of rocky shoreline, 3: Hydrodynamics of megaclast emplacement and transport on a shore platform, Oahu, Hawaii. Sedimentary Geology 172, 41-65.

Ovchinnikov, I., Götherström, A., Romanova, G., Kharitonov, V., Lidén, K. \& Goodwin, W., 2000. Molecular analysis of Neanderthal DNA from the northern Caucasus. Nature 404, 490-493.

Paffengol'ts, K.N. (Ed.), 1978. Geologitcheskij slovar'. [Geological dictionary]. Nedra, Moskva, 487 pp. (in Russian).

Pallí, L. \& Roqué, C., 1999. Restoration of a lost geological reference point: the loggingstone of Pedralta (Girona, Spain). [In:] D. Barettino, M.Vallejo \& E. Gallego (Eds): Towards the balanced management and conservation of the geological heritage in the new millenium. Sociedad Geológica de España, Madrid, 415-419.

Parry, R.H.G., 2000. Megalith mechanics. Proceedings of the Institution of Civil Engineers: Civil Engineering 138, 183-192.

Pettijohn, F.J., 1975. Sedimentary rocks. Harper and Row, New York, 628 pp.

Pinhasi, R., Higham, T.F.G., Golovanova, L.G. \& Doronichev, V.B., 2011. Revised age of late Neanderthal occupation and the end of the Middle Paleolithic in the northern Caucasus. Proceedings of the National Academy of Sciences 108, 8611-8616.

Powers, M.C., 1953. A new roundness scale for sedimentary particles. Journal of Sedimentary Petrology 41, 1069-1072.
Prosser, C.D., 2013. Our rich and varied geoconservation portfolio: the foundation for the future. Proceedings of the Geologists' Association 124, 568-580.

Prosser, C.D., Bridgland, D.R., Brown, E.J. \& Larwood, J.G., 2011. Geoconservation for science and society: challenges and opportunities. Proceedings of the Geologists' Association 122, 337-342.

Prosser, C., Murphy, M. \& Larwood, J., 2006. Geological conservation: a guide to good practice. English Nature, Peterborough, $145 \mathrm{pp}$.

Pugatchev, V.I. \& Ruban, D.A., 2007. Krupnye valuny kak ob'ekty geologitcheskogo nasledija. [Large boulders as objects of geological heritage]. [In:] V.I. Bakhtin, V.E. Kislov \& A.G. Mironov (Eds): Problemy geologii, mineral'nykh resursov $i$ geoekologii Zapadnogo Zabajkal'ja: Materialy mezhdunarodnoj nautchno-praktitcheskoj konferentsii. Izdatel'stvo BNTs SO RAN, Ulan-Ude, 144-146 (in Russian).

QPASMSA (Quarry Products Association and Silica and Moulding Sands Association), 2003. Geodiversity and the minerals industry - conserving our geological heritage. Entec UK Ltd., 17 pp.

Reynard, E., 2009. Geomorphosites and landscapes. [In:] E. Reynard, P. Coratza \& G. Regolini-Bissing (Eds): Geomorphosites. Dr. Friedrich Pfeil, München, 21-34.

Ruban, D.A., 2006. Standartizatsija opisanija geologitcheskikh pamjatnikov prirody kak vazhnykh ob'jectov natsional'nogo nasledija. [Standardization of descriptions of geological monuments of nature as important objects of the national heritage]. Geografija $i$ prirodnyje resursy 3, 166-168 (in Russian).

Ruban, D.A., 2010a. Quantification of geodiversity and its loss. Proceedings of the Geologists' Association 121, 326-333.

Ruban, D.A., 2010b. Unikal'nye tsentry georaznoobrazija - osnova dlja sozdanija natsional'nykh geoparkov. [Outstanding centers of geodiversity - a basis for the foundation of national geoparks]. Otetchestvennaja geologija 4, 77-80 (in Russian).

Ruban, D.A. \& Kuo, I., 2010. Essentials of geological heritage site (geosite) management: a conceptual assessment of interests and conflicts. Natura Nascosta 41, $16-31$.

Ruban, D.A. \& Pugatchev, V.I., 2008. Khadzhokhskij kan'on i Granitnoe utschel'e (Adygeja, Rossija) kak geologitcheskie pamajtniki prirody. [The Khadzhokhsky canyon and the Granitnoye gorge (Adygeia, Russia) as geological natural monuments]. Geografija $i$ prirodnye resursy 1, 62-66 (in Russian).

Straus, L.G., 2005. A mosaic of change: the Middle-Upper Paleolithic transition as viewed from New Mexico and Iberia. Quaternary International 137, 47-67.

Tiess, G., 2011a. General and international mineral policy. Focus: Europe. Springer, Wien, 620 pp.

Tiess, G., 2011b. Legal basics of mineral policy in Europe: an overview of 40 countries. Springer, Wien, 394 pp.

Tiess, G. \& Ruban, D.A., 2013. Geological heritage and mining legislation: a brief conceptual assessment of the principal legal acts of selected EU countries. Proceedings of the Geologists' Association 124: 411-416. 
Tost, M., Procter, J.N., Cronin, S.J. \& Neall, V.E., 2012. Stratigraphy, structure and emplacement mechanisms of one of the earliest Mt Ruapehu debris avalanche. [In:] A. Pittari \& R.J. Hansen (Eds): Abstracts. Geosciences 2012 Conference (Hamilton, New Zealand). Geoscience Society of New Zealand Miscellaneous Publication 134A, 88.

Trepet, S.A., 2011. Adygeja. [Adygeja]. Kubanskoe knizhnoe izdatel'stvo, Majkop, 80 pp. (in Russian).

Trepet, S.A., 2012. Bol'shaja Azishskaja petschera. [The Big Azish Cave]. Kubanskoe knizhnoe izdatel'stvo, Krasnodar, 64 pp. (in Russian).

Trepet, S.A., 2013. Vodopady Rufabgo. [The Rufabgo Waterfalls]. Kubanskoe knizhnoe izdatel'stvo, Krasnodar, 48 pp. (in Russian).

Tucker, M.E., 2011. Sedimentary rocks in the field. A practical guide. Wiley-Blackwell, Chichester, $276 \mathrm{pp}$.

Ufimtsev, G.F., Skovitina, T.M. \& Rezanov, I.N., 2004. Inskij sad kamnej. [The Inja stone garden]. Izdatel'stvo Instituta Geografii SO RAN, Irkutsk, 39 pp. (in Russian).

Wimbledon, W.A.P. \& Smith-Meyer, S. (Eds), 2012. Geoheritage in Europe and its conservation. ProGEO, Oslo, 405 pp.

Wimbledon, W.A., Benton, M.J., Bevins, R.E., Black, G.P., Bridgland, D.R., Cleal, C.J., Cooper, R.G. \& May, V.J., 1995. The development of a methodology for the selection of British geological sites for conservation: part 1. Modern Geology 20, 159-202.

Wimbledon, W., Ishchenko, A., Gerasimenko, N., Alexandrowicz, Z., Vinokurov, V., Liscak, P., Vozar, J., Bezak, V., Kohut, M., Polak, M., Mello, J., Potfaj, M., Gross, P., Elecko, M., Nagy, A., Barath, I., Lapo, A., Vdovets, M., Klincharov, S., Marjanac, L., Mijo- vic, D., Dimitrijevic, M., Gavrolovic, D., Theodossiou-Drandaki, I., Serjani, A., Todorov, T., Nakov, R., Zagorchev, I., Perez-Gonzalez, A., Benvenuti, M., Boni, M., Bracucci, G., Bortolani, G., Burlando, M., Costantini, E., D’Andrea, M., Gisotti, G., Guado, G., Marchetti, M., Massolli-Novelli, R., Panizza, M., Pavia, G., Poli, G., Zarlenga, F., Satkunas, J., Mikulenas, V., Suominen, V., Kananajo, T., Lehtinen, M., Gonggriijp, G., Look, E., Grube, A., Johansson, C., Karis, L., Parkes, M., Paudsep, R., Andersen, S., Cleal, C. \& Bevins, R., 1998. A first attempt at a GEOSITES framework for Europe - an IUGS initiative to support recognition of world heritage and European geodiversity. Geologica Balcanica 28, 5-32.

Manuscript submitted 12 August 2013 Revision accepted 7 November 2013 


\section{Appendix: Catalogue of the megaclast localities in Mountainous Adygeja (Western Caucasus, southwestern Russia) under study}

The present authors studied 8 localities in July 2013. In all of them, megaclasts occur within geosites, and contribute to their value as heritage objects and (geo)tourism attractions. In one case (the Maiden's Stone), the megaclast determines the very essence of the geosite. Figures 1-5 show the locations and megaclast views. More information about the geosites

\section{Khadzhokh Klamm}

Transliterated common name: Khadzhokhskaja tesnina.

Location: southern part of the town of Kamennomostskij, northern entrance to the Khadzhokh Canyon; tourist attraction 'Khadzhokhskaja tesnina'.

Geological setting: the Belaja River has incised a deep canyon in Late Jurassic limestones ending with a klamm (a narrow valley with vertical slopes and sometimes overhanging walls).

Megaclast occurrence: groups of megaclasts in the southern part of the klamm (at the toe of the left high overhanging wall) and in the northern part of the klamm (at the toe of the left high slope).

Megaclast age: Quaternary.

Megaclast rock composition: limestone.

Megaclast rock age: Late Jurassic.

Origin: colluvial.

Conservation status of the territory: regional (republican) natural monument.

Geosite: part of the Khadzhokh Canyon global-rank geosite (unofficial status).

Examined: July 16, 2013 by K.A.L. \& D.A.R.

\section{Rufabgo Canyon}

Location: the canyon of the Rufabgo River (left tributary of the Belaja River), the system of the Khadzhokh Canyon; tourist attraction 'Vodopady Rufabgo' (Rufabgo Waterfalls).

Geological setting: the Rufabgo River has incised a deep canyon in the intensively folded and faulted Triassic limestone-dom- detailed below can be found, particularly, in Lozovoj (1984), Pugatchev \& Ruban (2007), Ruban \& Pugatchev (2008), Ruban (2010a,b) and Trepet (2011, 2012, 2013). Many other megaclast localities are available in Mountainous Adygeja, where all slopes are affected by mass wasting processes.

inated flysch (the lower canyon level) and the unconformably overlying Late Jurassic limestones, which form a monocline (upper canyon level).

Megaclast occurrence: megaclasts (often in groups) along the entire canyon, co-existing with boulders.

Megaclast age: Quaternary.

Megaclast rock composition: limestone.

Megaclast rock age: Late Jurassic.

Origin: colluvial with alluvial influence.

Conservation status of the territory: regional (republican) nature monument.

Geosite: part of the Khadzhokh Canyon global-rank geosite (unofficial status).

Examined: July 9, 2013 by K.A.L. \& D.A.R.

\section{Maiden's Stone}

Transliterated common names: Devitchij kamen', Kazatchij kamen', and Tcherkesskij kamen'

Location: right slope of the Belaja River valley in the southern part of the Khadzhokh Canyon.

Geological setting: the Belaja River has incised a deep canyon in the Early-Middle Jurassic shales overlain by the Late Jurassic limestones.

Megaclast occurrence: an isolated megaclast in the middle part of the slope.

Megaclast age: Quaternary.

Megaclast rock composition: limestone.

Megaclast rock age: Late Jurassic.

Origin: colluvial.

Conservation status of the territory: regional (republican) nature monument. 
Geosite: part of the Khadzhokh Canyon global-rank geosite (unofficial status).

Examined: July 16, 2013 by P.P.Z. \& D.A.R.

\section{Prince's Hill (also known as Wildpig Mountain)}

Transliterated common names: Knjazheskij kholm and Kaban'ja gora

Location: north of the Doguako River (left tributary of the Belaja River).

Geological setting: the mountain exhibits a syncline composed mainly of Early-Middle Jurassic shales and overlain by Middle Jurassic encrinites exposed at the very top; it has evolved as an inversed landform (relief inversion).

Megaclast occurrence: rare megaclasts on mountain slopes, co-existing with boulders.

Megaclast age: Quaternary.

Megaclast rock composition: encrinite (crinoidal limestone).

Megaclast rock age: Middle Jurassic.

Origin: colluvial.

Conservation status of the territory: none.

Geosite: local-rank geosite (unofficial status).

Examined: July 20, 2013 by K.A.L. \& D.A.R.

\section{Azish-Tau Range}

Location: the cuesta-type range stretches as part of the Skalistyj Range between the Lago-Naki Highlands in the south-west and the Belaja River valley in the north-east, south of the 'Big Azish Cave' tourist attraction.

Geological setting: a monocline formed by Late Jurassic limestones and dolostones.

Megaclast occurrence: megaclasts co-existing with boulders in the roadcut, at the toe of the steep slope.

Megaclast age: Quaternary (possibly modern).

Megaclast rock composition: limestone and/or dolostone.

Megaclast rock age: Late Jurassic.

Origin: colluvial or anthropogenic.

Conservation status of the territory: none.
Geosite: part of the Lago-Naki Highlands national-rank geosite (unofficial status).

Examined: July 11, 2013 by K.A.L. \& D.A.R.

\section{Stonesea Range}

Transliterated common name: Kamennoe more.

Location: southern and south-eastern periphery of the Lago-Naki Highlands.

Geological setting: a monocline formed by Late Jurassic limestones and dolostones.

Megaclast occurrence: rare megaclasts, co-existing with rare scattered boulders near the top of the cliffs of the cuesta-type range; the megaclasts that were studied are located near the karst depression.

Megaclast age: Quaternary.

Megaclast rock composition: limestone and/or dolostone.

Megaclast rock age: Late Jurassic.

Origin: eluvial or colluvial.

Conservation status of the territory: Caucasian State Natural Biosphere Reserve.

Geosite: part of the Lago-Naki Highlands national-rank geosite (unofficial status).

Examined: July 11, 2013 by K.A.L. \& D.A.R.

\section{Permian Gorge}

Alternative transliterated name: Guzeripl'sko-Khamyshkinskoe utschel'e.

Location: between the town of Guzeripl' in the South and the village of Khamyshki in the North.

Geological setting: the Belaja River has incised a wide gorge in deformed red-coloured Permian molasse.

Megaclast occurrence: both isolated megaclasts and groups, co-existing with boulders at the toe of the steep gorge slopes and, particular$1 \mathrm{y}$, in the roadcut (left river bank).

Megaclast age: Quaternary (modern).

Megaclast rock composition: siliciclastic rocks.

Megaclast rock age: Early-?Middle Permian.

Origin: colluvial with possible anthropogenic influence.

Conservation status of the territory: none. 
Geosite: part of the Khamyshki Section national-rank geosite (unofficial status).

Examined: July 18, 2013 by P.P.Z. \& D.A.R.

\section{Guzeripl' Rockfall}

Location: $\sim 2 \mathrm{~km}$ north of the town of Guzeripl'. Geological setting: rockfall has affected the steep left slope of the gorge incised by the Belaja River in deformed Permian and Jurassic siliciclastic deposits.
Megaclast occurrence: megaclast co-existing with smaller particles (including boulders) along the rockfall.

Megaclast age: Quaternary (or even modern). Megaclast rock composition: sandstone.

Megaclast rock age: not established (Permian and/or Jurassic).

Origin: colluvial.

Conservation status of the territory: none.

Geosite: part of the Khamyshki Section national-rank geosite (unofficial status).

Examined: July 18, 2013 by P.P.Z. \& D.A.R. 